\title{
THE ROLE OF SELF-CONCEPT AND HEALTH LOCUS OF CONTROL ON QUALITY OF LIFE AMONG INDIVIDUALS WITH DIABETES
}

\author{
Tiara E. Octari ${ }^{1}$, Bambang Suryadi ${ }^{1}$, Dian R. Sawitri ${ }^{2}$ \\ ${ }^{1}$ Fakultas Psikologi, Universitas Islam Negeri Syarif Hidayatullah Jakarta, \\ Jalan Kertamukti No.5, Cireundeu, Jakarta 15412 \\ ${ }^{2}$ Fakultas Psikologi, Universitas Diponegoro \\ Jl. Prof. Soedarto, SH, Kampus UNDIP Tembalang, Semarang, Indonesia 50275 \\ tiaraersha@gmail.com
}

\begin{abstract}
Quality of life is an elemental factor for individuals with diabetes to improve health and reduce the risk of complications. Diabetics need to maintain their behavior to control blood sugar. With a locus of control and good self-concept, they will be able to improve their quality of life. The purpose of this study is to examine the role of self-concept and health locus of control on the quality of life among individuals with diabetes. This study used a quantitative approach involving 157 diabetics Jabodetabek. Nonprobability sampling technique, precisely the purposive sampling technique, was used to select the study sample. In collecting the data, three instruments were administered which consisted of a World Health Organization Quality of Life (WHOQOL-BREF) instrument with 26 items $(\alpha=.92)$, Revised Generalized Health-Related Self Concept Scale (RGHRSCS) with 25 items $(\alpha=.76)$, and Diabetes Locus of Control Scale (DLOCS) with 18 items (mean $\alpha=.71$ ). The multiple regression analysis applied to answer the research questions. The findings of this study indicate that there was a significant effect of self-concept and locus of health control on the quality of life of people with diabetes. Based on the minor hypothesis test, there were five significant variables, namely disposition of health protector $(b=.433, \mathrm{p}<.001)$, motivation to maintain health $(b=.176, p=.007)$, extrinsic motivation avoidance $(b=-.141, p=.033)$, internality $(b=.289, \mathrm{p}<.001)$, and other strong externalities $(b=.105, p=.017)$, whereas the other three variables are not significant, specifically vulnerability, health-risky habits, and chance externality.
\end{abstract}

Keywords: quality of life; self-concept; health locus of control; diabetes

\begin{abstract}
Abstrak
Kualitas hidup merupakan salah satu faktor penting bagi penyandang diabetes untuk meningkatkan kesehatan. Menjaga perilaku agar senantiasa dapat mengontrol gula darah merupakan hal penting untuk penyandang diabetes. Penelitian sebelumnya menunjukkan bahwa konsep diri dan lokus kontrol kesehatan merupakan faktor penting untuk meningkatkan kualitas hidup seseorang. Meskipun demikian, sedikit sekali penelitian yang menganalisis variabel konsep diri dan lokus kontrol kesehatan dengan penyandang penyakit diabetes. Penelitian ini bertujuan menguji pengaruh konsep diri dan lokus kontrol kesehatan terhadap kualitas hidup penyandang diabetes. Penelitian ini menggunakan pendekatan kuantitatif dengan melibatkan 157 penyandang diabetes yang ada di Jabodetabek. Pengambilan sampel dilakukan menggunakan non probability sampling technique. Alat ukur yang digunakan adalah World Health Organization Quality of Life (WHOQOL-BREF), Revised Generalized Health Related Self Concept Scale (RGHRSCS), dan Diabetes Locus of Control Scale (DLOCS). Teknik analisis data yang digunakan untuk menjawab pertanyaan penelitian adalah analisis regresi berganda. Hasil uji hipotesis mayor menunjukkan konsep diri dan lokus kontrol kesehatan berpengaruh secara signifikan terhadap kualitas hidup penyandang diabetes. Berdasarkan uji hipotesis minor, terdapat lima variabel yang signifikan, yaitu disposisi pelindung kesehatan, motivasi menjaga kesehatan, motivasi entrinsik penghindaran, internalitas dan eksternalitas kuat lainnya, sedangkan tiga variabel lainnya tidak signifikan,yaitu variabel kerentanan, kebiasaan berisiko kesehatan, dan peluang eksternalitas.
\end{abstract}

Kata kunci: kualitas hidup; konsep diri; lokus kontrol kesehatan; diabetes 


\section{INTRODUCTION}

In recent years, quality of life has become an important research issue and is increasingly being recognized as a way of measuring health care (Malkoc, 2011; Saravi, Navidian, Tabas, \& Shad, 2016; Utian, Janata, Kingsberg, Schluchter, \& Hamilton, 2018). This is also noted by the Center for Disease Control and Prevention (CDC), which has a target to improve the quality of life concerning health by 2020 . To develop this, knowledge of ways to improve the quality of life is urgently required (Lyu \& Wolinsky, 2017 ).

In a certain way, quality of life is also found to reduce the risk of diabetes (Norris, 2001; American Diabetes Association, 2019; Gebremedhin, Workicho, \& Angaw, 2019). Treatment guidelines published by the American Diabetes Associaton (2010) disclose the importance of maximizing health-related quality of life for adults with diabetes. Diabetes can be treated and its consequences can be eluded by improving the quality of life, which includes physical, emotional, and social welfare aspects such as physical function, limited role caused by physical or emotional problems, and energy level (Myers et al, 2013).

World Health Organization (WHO, 2017) discovered the fact that diabetic patients totaled 422 million people in 2014. In 2015, 1.6 million people died of diabetes, while another 2.2 million died due to high blood sugar in 2012. Also, WHO exposed that in 2012, around one million adults in the Southeast Asian region died from high blood sugar. For the Indonesian context, diabetes is the number one cause of death due to noncommunicable diseases. In 2014, people with diabetes in Indonesia reached 9.1 million people and ranked fifth in the world, from previously ranked 7th in 2013 (WHO, 2017; "Jakarta Diabetes Meeting", 2016).

Riset Kesehatan Dasar (Riskesdas) conducted by the Ministry of Health (2016) showed an increase in prevalence from 2007 of $5.7 \%$ to $6.9 \%$ in 2013. The International Diabetes Federation (2015) reports that in Indonesia, the estimated number of individuals with diabetes is estimated to reach 10 million inhabitants. Data on the Sample Registration Survey in 2014 shows that diabetes is the third largest cause of death in Indonesia with a percentage of $6.7 \%$ (Riskesdas, 2017).

Previous studies explained that diabetes lessens a person's quality of life. The decrease in quality of life can be even worse when accompanied by complications (Trikkalinou, Papazafiropoulou, \& Melidonis, 2017). Individuals with chronic diseases (including diabetes) have a low quality of life and have the potential to deviate from inadequate management of care resulting in poor clinical and psychological conditions (Bonomi, Patrick, Bushnell, \& Martin, 2000; Martinez, Aguilar, Pacheco-Rascon, \& Martinez, 2008; Tejada, Lynch, Storm, \& Egede, 2012). Each individual with the same clinical situation will portray a different quality of life. Nasiri et al., (2013) explained that quality of life helps nurses to understand patient health views and will facilitate patient care. Thus the treatment provided will be more effective and it will be easier to determine which treatment will be used according to the patient's condition. Eventually, it can determine strategies to improve the patient's quality of life.

Individuals' quality of life is predisposed by internal and external factors (Pukeliene \& Starkauskiene, 2011). On external, social and environmental factors are two things that affect the quality of life. In environmental aspects, an individual's quality of life is influenced by family support (Kaur, Kaur, \& Venkateashan, 2015). Whereas in the social aspect, social support, for example, influences the diabetic patient's treatment. The more received support, the greater the level of adjustment and the lower the manifestations of depression that will occur (Perez, Dell, \& Debora, 2014). Helgeson (2003) and Bélanger, et al., (2016) explained 
that social support and quality of life have a linear relationship. In other words, the higher the social support that individuals get, the higher the quality of life (LaRocca, \& Scogin, 2015).

On internal factors, previous studies have found that emotional levels, self-confidence, self-efficacy, and stress levels affect an individual's quality of life (Saravi, et al., 2017). In addition to these factors, there is one internal factor, explicitly the concept of self or subjective views, feelings, experiences, attitudes, beliefs, and conceptions about itself towards various elements in life. From this point of view, assessment of the quality of life needs to include the complex and personality structure of self-concept that refers to several subjective entities that are closely related to personal feelings and identity as important factors in evaluating the quality of life of a person (Zlatavonic, 2000). Studies have also proven that self-concepts are formed by interactions between social and physical characteristics, which reflect their selfrealization and acceptance (Clare et al., 2012). It was also stated that the higher the individual's self-concept would affect his mental health (Bharathi \& Sreedevi, 2013).

Vickery, Gontkovsky, and Caroselli (2005) explained that self-concept correlates with the quality of life, and shows that a low view of oneself is related to low quality of life. The study of Zlatanovic (2000) on quality of life proved that it is unbearable to disregard the individual's views about his feelings, experiences, beliefs, and conceptions. Several factors are needed to manage, control and slow down the risk of diabetes complications. Therefore, individuals with diabetes regarding their circumstances must continue to improve their self-concept, increase knowledge about diabetes and have a harmonious lifestyle (Williams, Lynch, Voronca, \& Egede, 2015).

Wiesmann, Niehorste, Hannich, and Hartmann (2008) define aspects of selfconcept namely protective disposition of health, motivation to maintain health, vulnerability, health risk habits, and avoidance extrinsic motivation. Health protective disposition is how the individual can maintain the stability of his commitment to health, self-confidence, and optimism. Mazanec (2010) exposed that optimism is significantly correlated with quality of life. Likewise, Kraai, Vermeulen, Hillege, Jaarsma, and Hoekstra (2017) stated that optimism is related to enhancing the quality of life.

Additionally to self-concept, health locus control is an often used parameter to measure health trust (Aliha, 2015; Rizza et al., 2015). The health locus of control is identified as a vigorous determinant of individual health behavior (Greene, Carolyn, \& Murdock, 2013). The health locus of control is a psychological factor that has been investigated as one of the predictors or determinants of health outcomes in chronic diseases (Wielengaboiten, Heijenbrok, \& Ribber, 2015). Individuals with a high locus of control have a high quality of life (Sharif, 2017). How individuals assess their sense of control has an impact on their quality of life and mental health (Kennedy, Lynch, \& Schwab, 1998; Cheng, Cecilia \& Cheung, 2013). Individual beliefs related to health, both control, and management, are also called health locus of control.

Based on the theory of planned behavior, the intention is needed to perform an individual's behavior. An individual can act based on his intention if he has control over his behavior. Whereas the locus of control has a role in an individual's (Haskas, Suryanto, \& Widodo, 2016). By having a good locus of control, individuals with diabetes have implications and a strong intention to exercise control over their diabetes. If they can improve their locus of control, they will be able to improve their quality of life through specific behavioral planning (Marrero et al, 2014; Haskas, et al., 2016). It is also known that having selfcontrol will improve health, life satisfaction and self-concept (Moffit et al., 2010; Sadaat, 
Ghasemzadeh, Karami, \& Soleimani, 2012; Bigdeloo \& Bozorgi, 2016).

Wallston, Wallston, Kaplan, and Maides (1976) identified three aspects of the health locus of control that is internality, other strong externalities and externality opportunities. Internality is how individuals perceive events that occur with their health are under their control and occur because of themselves. Russo et al. (2016) found that there was an influence of internal locus of control on the quality of life. Also, Sharif (2017) confirmed that individuals with a high internal locus of control will have a high quality of life too. Other external factors are how individuals perceive that their health is very dependent on factors outside themselves such as doctors, families, and therapists. Rintala, Paavilainen, and Astedt-Kurki (2013) exposed that families and significant others have an important role in diabetes management. It has been found that the locus of control affects the quality of life, but the subjects of previous studies were not people with diabetes (Helvik, et al., 2016). In previous studies, measures of quality of life were not focused on people with diabetes, but rather on nurses or caregivers (Du et al., 2017). The health enhancement of diabetic patients is very important. Although there were also studies that measure the quality of life of individuals with diabetes, they tend only to focus on external environmental factors and internal factors of self-efficacy and self-confidence, not on self-concept and health locus of control (Kaur et al., 2015; Keles, 2012; Saravi, et al., 2016).

The purpose of this study was to examine the relationship between self-concept and health locus of control on the quality of life of individuals with diabetes in the Greater Jakarta area. This study was aimed to measure the contribution of each dimension of selfconcept variables and health locus of control on the quality of life of individuals with diabetes. The results of this study are expected to add to the scientific field of psychology to improve the quality of life of diabetics people.

\section{METHOD}

\section{Participants}

The 157 study participants ranged in age from 40 to 80 . About $98(62.4 \%)$ were female and 59 men $(37.6 \%)$. The participants were selected using a non-probability sampling technique, explicitly purposive sampling technique with the criteria of having been diagnosed with type two diabetes by a doctor for at least six months and domiciled in Jabodetabek.

\section{Procedure}

Data were collected at the Diabetes Care Home (RUMAT) and the Indonesian Diabetes Association (PERSADIA). We read the questionnaires for participants who could not read or write, either because they did not bring glasses, or doing the treatment at the clinic. Before data collection, the research team asked participants' informed consent. Only those who are able and willing to be participants are asked to fill out the questionnaires.

\section{Instruments}

The measured quality of life, the World Health Organization Quality of Life (WHOQOL-BREF, 1997) was used. The reliability coefficient was .92. The questionnaire contains 26 items in 4 aspects of quality of life namely physical, psychological, social and environmental relations. Self-concept was measured by the Revised Generalize Health-related Self Concept Inventory (HRSCS) developed by Thomas and Moring (2014) with a reliability coefficient of .76. The instrument consisted of 25 items and covers 5 aspects of selfconcept specifically protective health disposition, motivation to maintain health, vulnerability, health risk habits, and extrinsic avoidance motivation.

The health locus of control was evaluated using the Diabetes Locus of Control Scale 
(DLCS). The instrument was developed by Ferraro, Price, Desmond, and Roberts (1987). This scale has three dimensions, namely internality, chance externality, and other powerful externalities with reliability coefficient .71. Each dimension consists of 6 items with the total items are 18. This measurement tool can be used for ages 18 to 80 years. The rating is provided using a 6point Likert scale.
We adapted the form of language translation from English into Bahasa Indonesia and changing the choice of answers. In the original measuring instrument, there are 7 answer choices on a Likert scale. The scale adapted and changed the choice of answers into 4 answer choices with a modified Likert scale. We did not add or reduce the number of items. The sample items from each measuring instrument are presented in Table 1.

Table 1.

Examples of Research Instrument Items

\begin{tabular}{lll}
\hline & \multicolumn{1}{c}{ Instrument } & \multicolumn{1}{c}{ Example Items } \\
\hline 1 & WHOQOL-BREF & How much do you enjoy life? \\
2 & HRSCS & In general, I practice healthy behavior \\
3 & DLCS & If I take care of myself, I can minimize the complications of diabetes \\
\hline
\end{tabular}

\section{Statistical analysis}

Data analysis was performed using multiple regression analysis consisting of one dependent variable, quality of life and eight independent variables namely healthprotective disposition, health-protective motivation, vulnerability, health-risky habits, extrinsic-avoidant motivation, internality, powerful other externality, and chance externality. The instrument validity test was carried out using Confirmatory Factor Analysis (CFA) using three criteria for valid items, namely: factor load must not be negative, t-value> 1.96 or $>-1.96$ and the number of error correlations between items maximum 3 .

Based on the CFA test, it was found that all factor load items both on the dimensions of self-concept and health locus of control had significant results. It can be concluded that the items were measuring the factors to be measured. However, there differences in the concept of self-concept, namely the dimensions of vulnerability. There is one item that is negatively charged and has no significant results.

\section{RESULTS AND DISCUSSION}

The results of this study will be classified into three parts. First, discusses the role of selfconcept and locus of control on the quality of life. Second, the contribution of self-concept to quality of life, and the third is the contribution of the health locus of control to quality of life. The descriptive analysis of the variables is presented in Table 2.

Table 2.

Descriptive Analysis ( $\mathrm{N}=157)$

\begin{tabular}{lccccc}
\hline & $\mathrm{N}$ & Minimum & Maximum & Mean & Std. Deviation \\
\hline Quality of life & 157 & 18.97 & 70.09 & 50.0000 & 9.71524 \\
Internality & 157 & 19.49 & 62.76 & 50.0000 & 9.55216 \\
Powerful other externality & 157 & 23.94 & 62.83 & 50.0000 & 9.72383 \\
Chance externality & 157 & 32.75 & 74.42 & 50.0000 & 9.36295 \\
Health protective disposition & 157 & 23.13 & 62.33 & 50.0000 & 9.47935 \\
Health protective motivation & 157 & 20.45 & 63.43 & 50.0000 & 9.45695 \\
Vulnerability & 157 & 34.66 & 68.36 & 50.0000 & 9.60431 \\
Health-risky habits & 157 & 31.80 & 74.03 & 50.0000 & 9.30818 \\
Extrinsic-avoidant motivation & 157 & 34.39 & 76.50 & 50.0000 & 8.67566 \\
\hline
\end{tabular}


Based on Table 2, it is shown that the variable with the highest maximum value is avoidance extrinsic motivation with a value of 76.50 , while the variable with the lowest minimum value is quality of life with a value of 18.97.
Then, we categorized each variable and applied the norm $\mathrm{X}<$ Mean was in a low category and $X>$ Mean was in the high category. Based on these norms, the categorization as presented in Table 3.

Table 3.

The Participants' Categorization

\begin{tabular}{lcccc}
\hline \multicolumn{1}{c}{ Variable } & Category & Frequency & Percentage & $\begin{array}{c}\text { Cumulative } \\
\text { Percent }\end{array}$ \\
\hline Quality of life & Low & 82 & 52 & 52.2 \\
Health protective disposition & High & 75 & 47.8 & 100.0 \\
& Low & 81 & 51.6 & 51.6 \\
Health protective motivation & High & 76 & 48.4 & 100.0 \\
& Low & 95 & 60.5 & 60.5 \\
Vulnerability & High & 62 & 39.5 & 100.0 \\
& Low & 92 & 58.6 & 58.6 \\
Health-risky habits & High & 65 & 41.4 & 100.0 \\
\multirow{2}{*}{ Extrinsic-avoidant motivation } & Low & 88 & 56.1 & 56.1 \\
& High & 69 & 43.9 & 100.0 \\
Internality & Low & 83 & 52.9 & 52.9 \\
\multirow{2}{*}{ Health protective disposition } & High & 74 & 47.1 & 100.0 \\
& Low & 82 & 52.2 & 52.2 \\
Chance externality & High & 75 & 47.8 & 100.0 \\
& Low & 95 & 60.5 & 60.5 \\
& High & 62 & 39.5 & 100.0 \\
& Low & 81 & 51.6 & 51.6 \\
\hline
\end{tabular}

Table 3 shows the majority of participants in this study were in the low category for each dimension. The results of this study also showed that the quality of life of individuals with diabetes was in a low category. This corroborates previous studies that said that individuals with chronic diseases (including diabetes) tend to have a low quality of life (Snel, et al., 2012; Nicolucci et al. 2013; Bonomi et al 2000, Martinez et al 2008, Tejada et al 2012). Individuals with a high quality of life will be able to reduce the risk of diabetes complications (Myers, 2013).

Next, we tested the hypothesis with multiple regression analysis techniques. The regression model was significant and acceptable $(\mathrm{F}(8,148)=58.859 ; \mathrm{p}<.001)$ with $\mathrm{R}=.872$ and $\mathrm{R}^{2}=.761$.

The model explaining that $76.1 \%$ of the variances the self-concept and health locus of control simultaneously affect the quality of life while the remaining $23.9 \%$ is influenced by other variables outside this study. The regression coefficient of each independent variable on quality of life can be seen in Table 4.

From the regression equation, it can be seen that there were five significant variables, specifically: (1) internality; (2) powerful other externality; (3) health-protective disposition; (4) health-protective motivation; and (5) extrinsic motivation for avoidance. 
Based on Table 4, it can be viewed as the stronger regression coefficient. In this case, we use the standardized coefficient or beta $(\beta)$ to see which regression coefficient number shows a stronger influence on the dependent variable. The health-protective disposition variable has the strongest influence with $\beta=$ .422 .

Table 4.

The Regression Coefficient of The Independent Variable

\begin{tabular}{llll}
\hline Independent variable & $\beta$ & $t$ & $P$ \\
\hline Internality & .284 & 5.186 & $.000^{* *}$ \\
Powerful other externality & .105 & 2.413 & $.017^{*}$ \\
Chance externality & .023 & .479 & .632 \\
Health protective disposition & .422 & 6.271 & $.000^{* *}$ \\
Health protective motivation & .171 & 2.721 & $.007 * *$ \\
Vulnerability & -.086 & -1.652 & .101 \\
Health-risky habits & .061 & .973 & .332 \\
Extrinsic-avoidant motivation & -.126 & -2.157 & $.033^{*}$ \\
\hline
\end{tabular}

Note: $* p<.05 ; * * p<.01$

To found out the influence of self-concept on health locus of control, we looked at the significance of the ANOVA test and found the significance of $p<.001$, which means selfconcept and health locus of control were a significant impact on the quality of life. These results are consistent with research conducted by Vickery et al. (2005) and Clare et al.
(2012) which showed a significant influence of self-concept on quality of life and Marrero et al (2014) research which showed a significant influence of the locus of control on the quality of life. Meanwhile, to figure out the contribution of self-concept to quality of life, we tested the proportion of variance as presented in Table 5.

Table 5.

Variants' Proportion

\begin{tabular}{|c|c|c|c|c|c|c|c|}
\hline \multirow[t]{2}{*}{ Model } & \multirow[t]{2}{*}{$\mathrm{R}$} & \multirow[t]{2}{*}{ R Square } & \multicolumn{5}{|c|}{ Change Statistics } \\
\hline & & & $\begin{array}{c}\text { R Square } \\
\text { Change }\end{array}$ & F Change & df1 & df2 & Sig. F Change \\
\hline 1 & $.697^{\mathrm{a}}$ & .486 & .486 & 146.402 & 1 & 155 & $.000 * *$ \\
\hline 2 & $.740^{\mathrm{b}}$ & .548 & .062 & 21.070 & 1 & 154 & $.000 * *$ \\
\hline 3 & $.752^{\mathrm{c}}$ & .566 & .018 & 6.357 & 1 & 153 & $.013 *$ \\
\hline 4 & $.855^{\mathrm{d}}$ & .731 & .166 & 93.650 & 1 & 152 & $.000 * *$ \\
\hline 5 & $.864^{\mathrm{e}}$ & .746 & .015 & 8.965 & 1 & 151 & $.003 * *$ \\
\hline 6 & $.868^{\mathrm{f}}$ & .753 & .007 & 4.264 & 1 & 150 & $.041^{*}$ \\
\hline 7 & $.868^{\mathrm{g}}$ & .753 & .000 & .007 & 1 & 149 & .932 \\
\hline 8 & $.872^{\mathrm{h}}$ & .761 & .008 & 4.657 & 1 & 148 & $.033^{*}$ \\
\hline
\end{tabular}

Information:

Model 1: Influence of internality on quality of life

Model 2: Influence of powerful other externality on quality of life

Model 3: Influence of chance externality on quality of life

Model 4: Influence of health-protective disposition on quality of life

Model 5: Influence of health-protective motivation on quality of life

Model 6: Influence of vulnerability on quality of life

Model 7: Influence of health-risky habits on quality of life

Model 8: Influence of extrinsic motivation for avoidance on quality of life

$*=\mathrm{p}<.05 ; * *=\mathrm{p}<.01$ 
The health protection disposition dimension significantly contributed $16.6 \%$ of variance to the quality of life $(\mathrm{F}[1,152]=93.650, \mathrm{p}=$ .000). Diabetics who have a good healthprotective disposition are said to have high optimism. In this study, some participants had low health-protective disposition. Previous studies said high optimism is needed among individuals with diabetes because it will help improve self-care (Fournier \& Bensing, 2002; Nicolucci et al., 2013). It was also detailed that there is some evidence that optimism and pessimism have different effects on the outcome of health adjustments (Kreis, Zenasni, Fautrel, \& Gossec, 2014). Optimism is significantly associated with a high level of quality of life (Kreis et al, 2014).

The dimension of health-protective motivation contributed $1.5 \%$ in the variance of quality of life with $(\mathrm{F}[1,151]=8.965$ and $p=.003)$. Health protective motivation was found positively significant influences the quality of life. It can be said that the higher the motivation for maintaining health, the higher the quality of life. These results corroborate the previous study which says that the importance of motivation for patients with diabetes, and the relationship between motivation and glycemic control can be used as an approach to enhance diabetes management. It means a great deal for patients with poor diabetes control since it can prevent complications (Osborn \& Egede, 2010). It was also stated that motivation is one of the factors that positively influence the quality of life (Grübler \& Hildt, 2014).

The vulnerability dimension supplied $.7 \%$ in the quality of life variance $(\mathrm{F}[1,150]=4.264$, $\mathrm{p}=.041)$. The dimensions of vulnerability provide significant results, which are in line with previous studies as the high levels of individual vulnerability will provide poor psychological and health conditions. Further, Waitman et al (2016) mentioned that there was a significant influence on the susceptibility of individuals with diabetes to quality of life. Vulnerability is one of the non-conventional factors that cause abnormal blood sugar. These conditions will interfere with both psychological and health conditions and diminished quality of life. It is well said that individuals with high levels of vulnerability will cause feelings of hopelessness accompanied by a decrease in quality of life (Abramson, Alloy, \& Metalsky, 1989; Alloy et al, 1999).

The dimension of health risk habits found not significantly influence the quality of life $(\mathrm{F}[1,149]=.007, \mathrm{p}=.932)$. Contradictory with Rosiek et al (2017) study which found a healthy lifestyle, and preventive health behavior and adequate nutritional habits are the keys to diabetes treatment and crucially prevent complications. Further, Rosiek et al (2017) explained that individuals with healthy behaviors habit significantly influence their life satisfaction. It has also been explained that the knowledge and sense of duty of individuals with diabetes in maintaining their health must be improved. Also, controlling blood sugar, implementing healthy behaviors, maintaining eating patterns and avoiding health-risk habits (Low, Tong, \& Low, 2014; Rintala, Paavilainen, \& Astedt-Kurki, 2013; Hart, Benavidez, \& Erickson, 2017; Jing, et al, 2018; Canadian Institute for Health Information, 2011). In this study, the majority of participants had habits that had a risk to their health.

While the last dimension of self-concept namely extrinsic motivation for avoidance significantly contributed $0.8 \%$ in the variance of quality of life $(F[1,148]=4.657, p=.033)$. Extrinsic motivation for avoidance has a negative significant effect on the quality of life. The higher the extrinsic motivation for avoidance individuals with diabetes had, the lower the quality of life. It can be said that the more individuals show resignation, fear of their health condition, the lower the quality of life. These results are consistent with previous research which says that motivation 
will affect individual diabetes control and will make it easier for individuals with diabetes to control their blood sugar. Similarly, personal motivation is related to behavior, as a predictor of blood sugar control (Osborn, 2010; Copeland, 2015; Papies, 2016).

Specifically, it was found that internality dimension positively significant contributed dominantly $48.6 \%$ to health locus of control variable $(48.6 \% \mathrm{~F}[1,155]=146.402, \mathrm{p}=$ $.000)$. Then it can be said that the higher the internality, the higher the quality of life. The study of Russo et al. (2016) concluded that there was a significant influence between the internal control locus on quality of life. Individuals with a good health locus of control can well manage their health because of self-confidence in themselves that health status can be maintained with healthy behaviors. Individuals with a high internal control locus will have a high quality of life too (Sharif, 2017). Similarly associated with good health behavior and psychological state improvement (Oberle, 1991; Stewart \& Yuen, 2011).

Further, powerful another externality dimension significantly contributed $6.2 \%$ in quality of life variance $(F[1,154]=21.070, p$ $=.000)$, the powerful other externalities positively influencing the quality of life. Then, the higher the powerful other externalities, the higher the quality of life. Strengthening Russo et al. (2016) about the significant role of another externality locus of control toward the quality of life. It emphasized the important role of family and significant others to improve individual health status by supporting through maintaining diet, dietary intake and schedule control (Rintala, Paavilainen, \& AstedtKurki, 2013). Previous research confirmed support form can enhance healthy behaviors, minimize health risk behaviors and affect the glycemic control of diabetic patients (Mayberry \& Osborn, 2012). Health services and good handling of medical personnel are also quality of life-improving among individuals with diabetes (Low et al., 2014).

Whilst the dimensions of chance externality contributed $1.8 \%$ in the variance of quality of life $(F[1,153]=6.357, p=.013)$. Undermined Marrero et al (2014) study which showed a significant influence between the locus of control and quality of life. Diabetics with a higher probability of externalities shown beliefs about health is not depend on internal and external factors (doctors, family, drugs, etc.) nonetheless interrelated to destiny, luck, and chance. This dimension has no significant effect on the quality of life. Unlike Wielengaboiten et al. (2015) which found a significant effect on externalities on quality of life. Most individuals with diabetes consider their health independent from internal factors and strong externalities such as family, doctor, nurse or maybe other diabetics.

Based on the contribution $\left(\mathrm{R}^{2}\right.$ value) as presented in Table 5, it can be concluded that there were seven significant variables influence the quality of life. It was internality, health-protective disposition, powerful other externality, chance externality, healthprotective motivation, extrinsic motivation for avoidance and vulnerability. While health-risky habits significantly not contribute at all.

These findings have implications for individuals with diabetes to improve their health. It is imperative to have a positive selfconcept, understand the risk of diabetes complications, higher motivation to maintain health and being confident about the linearity of health condition and health maintaining effort. Though, support from other parties such as family and doctors is needed so that individuals with diabetes can improve their health.

\section{CONCLUSION}

This study evaluated the role of self-concept and health locus of control on the quality of 
life among diabetic. The findings indicate that self-concept and health locus of control affect the diabetic's quality of life. Improving their quality of life is needed, considering the risk of diabetes complications is significant in their health conditions. The implications of this study for people with diabetes are to be able to increase their internality factors, believing that their health is influenced by their efforts and behavior. Further, for families, it is expected to always provide support, guidance and routine assistance in control the diabetics' health.

\section{REFERENCES}

Abramsom, L., Alloy, L., \& Metalsky, G. (1989). Hopelessness depression: a theory-based subtype of depression. American Psychological Association, 96(2), 358-372. doi: 10.1037/0033295X.96.2.358.

Aliha, J. M., (2015). The relationship between quality if life and health locus of control beliefs in hemodialysis patients. JCCNC, I(2), 83-90.

Alloy, L., Abramson, L. Y., Whitehouse, W. G., Hogan, M. G., Tashman, N. A., Steinberg, D. L., Rose, D. T., Donovan, P. (1999). Depresogenic cognitive styles: Predictive validity, information processing and personality characteristics, and developmental origins. Behavior Research and Therapy, 37(6), 503531. doi: 10.1016/S00057967(98)00157-0.

American Diabetes Association. (2010). Definition and characteristic of diabetes. Diabetes Care Journal, 33(1), 62-69. doi: 10.2337/dc10s062.

American Diabetes Association. (2010). Standards of medical care in diabetes2010. Diabetes Care, 33(1), 11-61. doi: $10.2337 / \mathrm{dc} 10-\mathrm{S} 011$.
American Diabetes Association (2019). Introduction: Standards of medical care in diabetes. Journal of Clinical and Applied Research and Education, 42(1), 51-52. doi: 10.2337/dc19Sint01.

Bélanger E, Ahmed, T., Vafaei, A., Curcio, C. L., Phillips, S. P., Zunzunegui, M. V. (2016). Sources of social support associated with health and quality of life: a cross-sectional study among Canadian and Latin American older adults. BMJ Open, 6(6), 1-10. doi: 10.1136/bmjopen-2016-011503.

Bharathi, T. A., \& Sreedevi, P. (2016). Study on the self-concept of adolescents. International Journal of Science and Research, 5(10), 512-516.

Bigdeloo, M. \& Bozorgi, Z. D. (2016). Relationship between the spiritual intelligence, self-control, and life satisfaction in high school teachers of mahshahr city. Review of European Studies, $\quad 8(2), \quad 210 . \quad$ doi: $10.5539 /$ res.v8n2p210.

Bonomi, A. E., Patrick, D. L., Bushnell, D. M., \& Martin, M. (2000).Validation of the united states' version of the world health organization quality of life (whoqol) instrument. Journal of Clinical Epidemiology, 53(1), 1-12. doi: 10.1016/S0895-4356(99)001237.

Canadian Institute for Health Information (2011). Health care in Canada "A focus on senior and aging". Canada, Ottawa: CIHI.

Cheng, C., Cheung, S. F., Chio, J. H., \& Chan, M.-P. S. (2013). Cultural meaning of perceived control: A meta-analysis of locus of control and psychological symptoms across 18 cultural regions. Psychological Bulletin, 139(1), 152-188. doi:10.1037/a0028596 
Clare, L., Whitaker, C. J., Nelis, S. M., Martyr, A., Markova, I. S., Roth, I., Woods, R. T., \& Morris, R. G. (2012). Self-concept in early stage dementia: profile, course, correlates, predictors and implications for quality of life. International Journal of Geriatric Psychiatry, 28(5), 494-503. doi:10.1002/gps.3852

Copeland, L., McNamara, R., Kelson, M., \& Simpson, S. (2015). Mechanisms of change within motivational interviewing in relation to health behaviors outcomes: A systematic review. Patient Education and Counseling, 98(4), 401-411. doi:10.1016/j.pec.2014.11.022

Du, J., Shao, S., Jin, G. H., Qian, C. G., Xu, W., \& Lu, X. Q. (2017). Factors associated with health related quality of life among family caregivers of disabled older adults: A crosssectional study from beijing. Medicine, 96(44), e8489. doi:10.1097/ MD.0000000000008489.

Ferraro, A. L., Price, J. H., Desmond, S. M., \& Roberts, S. M. (1987). Development of a diabetes locus of control scale. Psychological Reports, 61(3), 763-770. doi:10.2466/pr0.1987.61.3.763.

Fournier, M. R., \& Bensing, J. (2002). Optimism and adaptation to chronic disease: the role of optimism in relation to self-care options of type 1 diabetes mellitus, rheumatoid arthritis and multiple sclerosis. British Journal of Health Psychology, 7(4), 409-432. doi: 10.1348/135910702320645390.

Gebremedhin, T., Workicho, A., \& Angaw, D. A. (2019). Health-related quality of life and its associated factors among adult patients with type II diabetes attending Mizan Tepi
University Teaching Hospital, Southwest Ethiopia. BMJ Open Diabetes Research \& Care, 7(1), doi:10.1136/bmjdrc-2018-000577

Greene, A. Carolyn \& Murdock, K. Klein. (2013). Multidimensional control beliefs, socioeconomic status, and health. American Journal of Health Behavior, 37(2), 227-237. doi: 10.5993/AJHB.37.2.10

Grübler, G., \& Hildt, E. (Eds.). (2014). BrainComputer-Interfaces in their ethical, social and cultural contexts. The International Library of Ethics, Law and Technology, doi:10.1007/97894-017-8996-7.

Hart, P. D., Benavidez, G., \& Erickson, J. (2017). Meeting Recommended Levels of Physical Activity in Relation to Preventive Health Behavior and Health Status Among Adults. Journal of preventive medicine and public health, 50(1), 10-17. doi:10.3961/jpmph.16.080.

Haskas, Y., Suryanto, \& Widodo. (2016). The effect of locus of control on the diabetes mellitus patients intention in performing the $\mathrm{dm}$ control. International Journal of Sciences Basic and Applied Research (IJSBAR), 25(2), 130-136, ISSN:2307 4531

Helvik, A.-S., Bjørkløf, G. H., Corazzini, K., Selbæk, G., Laks, J., Østbye, T., \& Engedal, K. (2016). Are coping strategies and locus of control orientation associated with healthrelated quality of life in older adults with and without depression?. Archives of Gerontology and Geriatrics, 64, 130-137. doi:10.1016/j.archger.2016.01.014

Ikatan Dokter Indonesia. (2016). Jakarta Diabetes Meeting 2016: Perawatan Diabetes Secara Menyeluruh. 
Retrieved

http://www.idionline.org/

berita/jakarta-diabetes-meeting-

2016-perawatan-diabetes-secara-

menyeluruh/.

International Diabetes Federation (2015).

International Diabetes Federation:

Diabetes Atlas (7th ed.). Retreived fro https://www.idf.org/component/attac hments/attachments.html?id=1093\&t ask $=$ download

Jing, X., Chen, J., Dong, Y., Han, D., Zhao, H., Wang, X., Ma, J. (2018). Related factors of quality of life of type 2 diabetes patients: a systematic review and meta-analysis. Health and Quality of Life Outcomes, 16(1). doi:10.1186/s12955-018-1021-9

Kaur, H., Kaur H., \& Venkateashan, M. (2015). Factors determining family support and quality of life of elderly population. International Journal of Medical Science and Public Health. doi: $\quad$ 10.5455/ijmsph.2015.2101201 5220 .

Keles, R. (2012). The quality of life and the environment. Social and Behavioral Sciences, 35, 23-32. doi: 10.1016/j.sbspro.2012.02.059.

Kemenkes. (2016). Menkes: Mari Kita Cegah Diabetes dengan Cerdik. Retrieved from

http://www.depkes.go.id/article/print /16040700002/menkes-mari-kitacegah-diabetes-dengan-cerdik.html

Kennedy, L. B., Lynch, V. G., \& Schwab, J. J. (1998). Assessment of locus of control in patients with anxiety and depressive disorders. Journal of Clinical Psychology, 54(4), 509-515. doi: $\quad 10.1002 /$ (sici)10974679(199806)54:4<509::aidjclp12>3.0.co;2-j.
Kraai, I. H., Vermeulen, K. M., Hillege, H. L., Jaarsma, T., \& Hoekstra, T. (2017). Optimism and quality of life in patients with heart failure. Palliative and Supportive Care, 1-7. doi:10.1017/S1478951517001055

Kreis, S., Zenasni, F., Fautrel, B., \& Gossec, L. (2014). AB1162-HPR Relationship between Optimism and Quality of Life in Patients with Chronic Rheumatic Diseases: A Systematic Literature Review. Annals of the Rheumatic Diseases, 73(2), 1221-1222.

doi:10.1136/annrheumdis-2014eular.3538

LaRocca, M. A., \& Scogin, F. R. (2015). The Effect of Social Support on Quality of Life in Older Adults Receiving Cognitive Behavioral Therapy. Clinical gerontologist, 38(2), 131148.

doi:10.1080/07317115.2014.990598

Low, L. L., Tong, S. F., \& Low, W. Y. (2014). Mixed feelings about the diagnosis of type 2 diabetes mellitus: a consequence of adjusting to health related quality of life. Coll Antropol, 38(1), 11-20

Lyu, Wei \& Wilonsky, F. D. (2017). The onset of adl difficult and changes in health-related quality of life. Health and Quality of Life Outcomes, 15(1). doi:10.1186/s12955-017-0792-8.

Malkoç, A. (2011). Quality of life and subjective well-being in undergraduate students. Procedia Social and Behavioral Sciences, 15, 2843-2847.

doi:10.1016/j.sbspro.2011.04.200

Marrero, D., Pan, Q., Barret-Connor, E., De Groot, M., Zhang, P., Percy, C., Florez, H., Ackermann, R., Montez, M., \& Rubin, R. R. (2014). Impact of diagnosis of diabetes on health- 
related quality of life among high risk individuals: the diabetes prevention program outcomes study. Quality Life Res, 23(1), 75-88. doi: 10.1007/s11136-013-0436-3.

Martinez, V. Y., Aguilar, C. A. P. PachecoRascon, A. R., \& Martinez, J. V. J. (2008). Quality of life associated with treatment adherence in patients with type 2 diabetes: A cross-sectional study. BMC Health Services Research, 8(1). doi:10.1186/14726963-8-164.

Mayberry, S. L., \& Osborn, Y. C. (2012). Family support, medication adherence and glycemic control among adults with type 2 diabetes. American Diabetes Association Diabetes Care, 35(6), 1239-1245. doi: $10.2337 / \mathrm{dc} 11-2103$

Mazanec, R. S., Daly, B. J., Douglas, L. S., \& Lipson, A. R. (2010). The relationship between optimism and quality of life in newly diagnosed cancer patients. Wolter Kluwer Health Cancer Nursing, 33(3), 235243. doi: 10.1097/NCC.0b013e3181c7fa80.

Moffitt, T. E., Arseneault, L., Belsky, D., Dickson, N., Hancox, R, J., Harrington, H., Houts, R., Poulton, R., Roberts, B. W., Ross, S., Sears, M. R., Thomson, W. M., \& Caspi, A. (2010). A gradient of childhood selfcontrol predict heath, wealth, and public safety. Proceedings of the National Academy of Sciences, 108(7), 2693-2698. doi: /10.1073/pnas.10.10076108.

Myers, H. V., McVay, A. M., Brashear, M. M., Johannsen, M. N., Swift, L. D., Kramer, K., Harris, N. M., Earnest, P. C., \& Church, S. T. (2013). Exercise training and quality of life in individuals with type 2 diabetes.
Diabetes Care, 36, 1884-1890. doi:10.2337/dc1201153

Nasiri, Mahboobeh., Kheirkhah, Farzan., Rahimiyan, Behnaz., Ahmadzadeh, Bijan., Hasannejad, Hosein., Jahfari, M. R. (2013). Stressful Factors, Coping Mechanism and Quality of Life in Hemodialysis Patients. Iran J Crit Care Nurs, 6(2), 119-126.

Nicolucci, A., Burns, K. K., Holt, R. I. G., Comaschi, M., Hermanns, N., Ishii, H., Kokoszka, A., Pouwer, F., Skovlund, E., Stuckey, H., Tarkun, I., Vallis, M., Wens, J., \& Peyrot, M. (2013). Educational and psychological issues diabetes attitudes, wishes and needs second study (DAWN2): Cross-national benchmarking of diabetes-related psychosocial putcomes for people with diabetes. Diabetic Medicine,30(7), 767-777. doi: 10.1111/dme.12245.

Norris, S. L., Engelgau, M. M., \& Narayan, K. M. V. (2001). Effectiveness of self-management training in type 2 diabetes. Diabetes Translation, National Center for Chronic Disease Prevention and Health Promotion, Centers for Disease Control and Prevention. Diabetes Care, 24(3), 561-587. doi: 10.2337/diacare.24.3.561.

Oberle, K. (1991). A decade of research in locus of control: What have we learned? Journal of Advanced Nursing, 16(7), 800-806. doi: $10.1111 / \mathrm{j} .1365-$ 2648.1991.tb01759.x.

Osborn, Y. C., \& Egede, E. L. (2010). Validation of an informationmotivation-behavioral skills model of diabetes self-care (IMB-DSC). Patient Education and Counselling, 79(1), 49-54. doi:10.1016/j.pec.2009.07.016 
Papies, E. K. (2016). Health goal priming as a situated intervention tool: How to benefit from nonconscious motivational routes to health behavior. Health Psychology Review, 10(4), 408-424. doi: 10.1080/17437199.2016.1183506.

Perez, C. L., Dell, A., \& Debora, D. (2014). Health related quality of life and social support in adolescents with type 1 diabetes. Spanish Journal of Psychology, 17(108), $1-9$ doi:10.1017/sjp.2014.101.

Pukeliene, V., \& Starkauskiene, V. (2011). Quality of life: factors determining its measurement complexity. Inzinerine Ekonomika_Engineering Economics, 22(2), 147-156, doi:10.5755/j01.ee.22.2.311

Rintala, T., Paavilainen, E., \& Astedt-Kurki, P. (2013). Everyday living with diabetes described by family members of adult people with type 1 diabetes. International Journal of Family Medicine, 2013(967872), 1-8, doi:10.1155/2013/967872.

Riskesdas. (2017). Tekan angka kematian melalui program Indonesia sehat dengan pendekatan keluarga. Retrieved from http://www.depkes.go.id/pdf.php?id $=17061600003$

Rizza, F., Gison, A., Bonassi, S., Dall'Armi, V., Tonto, F., \& Giaquinto, S. (2015). "Locus of control", health-related quality of life, emotional distress and disability in Parkinson's disease. Journal of Health Psychology, 22(7), 844-852. doi:10.1177/1359105315616471.

Rosiek, A., Kornatowski, T., FrackowiakMaciejewska, N., RosiekKryszewska, A., Wyżgowski, P., \& Leksowski, K. (2016). Health behaviors of patients diagnosed with type 2 diabetes mellitus and their influence on the patients' satisfaction with life. Therapeutics and Clinical Risk Management, 12, 1783-1792. doi:10.2147/tcrm.s118014.

Russo, G. T., Scavini, M., Acmet, E., Bonizzoni, E., Bosi, E., ... Giorgino, F. (2016). the burden of structured self-monitoring of blood glucose on diabetes-specific quality of life and locus of control in patients with noninsulin-treated type 2 diabetes: The PRISMA Study. Diabetes Technology \& Therapeutics, 18(7), 421-428. doi:10.1089/dia.2015.0358.

Saadat, M., Ghasemzadeh, A., Karami, S., \& Soleimani, M. (2012). Relationship between self esteem and locus of control in Iranian University students. Procedia - Social and Behavioral Sciences, 31, 530-535. doi:10.1016/j.sbspro.2011.12.099.

Saravi, F. K., Navidian, A., Tabas, E. E., \& Shad, T, S. (2016). Prediction of the quality of life in the adolescenta with diabetes based on self-efficacy. Medical-Surgirical Nursing Journal, 5(3), 43-49.

Sharif, S. P. (2017). Locus of control, quality of life, anxiety and depression among Malaysian breast cancer patients: the mediating role of uncertainty. European Journal of Oncology Nursing, 27, 28-35, doi:10.1016/j.ejon.2017.01.005.

Snel, M., Sleddering, M. A., vd Peijl, I. D., Romijn, J. A., Pijl, H., Meinders, A. E., \& Jazet, I. M. (2012). Quality of life in type 2 diabetes mellitus after a very low calorie diet and exercise. European Journal of Internal Medicine, 23(2), 143-149. doi:10.1016/j.ejim.2011.07.004.

Stewart, D. E., \& Yuen, T. (2011). A systematic review of resilience in the 
physically ill. Psychosomatics, 52(3), 199-209.

doi:10.1016/j.psym.2011.01.036.

Tejada, H., Lynch, C., Storm, J., \& Egede, L. (2012). Effect of perceived control on quality of life in indigent adults with type 2 diabetes. Diabetes Educ, 38(2), 256-262. doi: $10.1177 / 0145721711436135$.

Thomas, J. J., \& Moring, J. C. (2014). Development of a revised generalized health-related selfconcept inventory. American Journal of Health Behavior, 38(4), 614623. doi:10.5993/ajhb.38.4.15.

Trikkalinou, A., Papazafiropoulou, K. A., \& Melidonis, A. (2017). Type 2 diabetes and quality of life. World Journal of Diabetes, $\quad 8(4), \quad 120-129$. doi:10.4239/wjd.v8.i4.120.

Utian, W. H., Janata, J. W., Kingsberg, S. A., Schluchter, M., \& Hamilton, J. C. (2018). The Utian Quality of Life (UQOL) Scale. Menopause, 25(11), 1224-1231. doi:10.1097/gme.000000000000122 3.

Vickery, C., Gontkovsky, T., \& Caroselli, J. (2005). Self-Concept and quality of life following acquired brain injury: A pilot investigation. Brain Injury, 19(9), 657-665. doi:10.1080/02699050400005218.

Waitman, J., Caeiro, G., Gonzalez, S. A. R., Danila, P. Re., Daghero, A., Gonzalez, D. C., \& Umpierrez, E. G. (2016). Social vulnerability and hypoglycemia among patients with diabetes. Endocrinol Diabetes $y$ Nutrición, 64(2), 92-99. doi:10.1016/j.endinu.2016.11.008.

Wallston, B. S., Wallston, K. A., Kaplan, G. D., \& Maides, S. A. (1976). Development and validation of the Health Locus of Control (HLC) Scale. Journal of Consulting and Clinical Psychology, 44(4), 580585. doi:10.1037/0022-

006x.44.4.580

Wielengaboiten, E. J., Heijenbrok, H. M., \& Ribbers, M. G. (2015). The relationship of health locus of control and health-related quality of life in the chronic phase after traumatic brain injury. Journal of Head Trauma Rehabilitation, 30(6), 424-431. doi: 10.1097/HTR.0000000000000128.

Wiesmann, U., Niehörster, G., Hannich, H.J., \& Hartmann, U. (2008). Dimensions and profiles of the generalized health-related selfconcept. British Journal of Health Psychology, 13(4), 755771. doi:10.1348/135910707x25669 9.

Williams, J. S., Lynch, C. P., Voronca, D., \& Egede, L. E. (2015). Health locus of control and cardiovascular risk factors in veterans with type 2 diabetes. Endocrine, 51(1), 8390. doi:10.1007/s12020-015-0677-8.

World Health Organization. (1997). Division of Mental Health and Prevention of Substance Abuse. Diunduh dari http://who.int/iris/handle/10665/6348 2.

World Health Organization. (2017). Diabetes Key Facts. Diunduh dari http://www.who.int/news-room/factsheets/detail/diabetes.

Zlatanovic, L. (2000). The role of the person's self-concept in quality of life research. The Scientific Journal Series Phylosophy and Sociology, 2(7), 391-3 